\title{
The Romantic Frame of Touristic Culture
}

\author{
Jose Manuel Figueiredo Santos
}

$\mathrm{PhD}$ in Sociology of Culture ESGHT - Universidade do Algarve, Portugal

\begin{abstract}
This essay justifies its usefulness in the search for the Romantic movement contributions to a structured understanding of tourism, on the assumption that it is in historically built forms of the spatiotemporal imaginary that are found under rejuvenated forms, many of the old assumptions that incorporate contemporary tourism.

In terms of methodology, this narrative is permeated by a historical meta-speech of phenomenological influence that had as sources a huge documental mass collected by the author within his doctoral thesis, finding in the romantic historiography a field of exceptional potential to test the heuristic resources and the explanatory possibilities of some contemporary tourism stylizations, associated with tourist use of cultural heritage.

In fact, the emergence and edification of tourism, by being pierced by an historical seminal influence of Romantic culture makes it necessary to address the characterization of some of its essential features. We do not seek to question their enigmas or its "coincidentia oppositorum nature" (Lowy 1995: 9), but some fundamental drifts such as: a specific aesthetic sensibility of the cult of strong emotions, and utopian projections of a world of beauty created by imagination, the regenerating momentum of the past, as an operator of the inspirational mysticism and taste. In them, we deposit the purpose of extracting the elements of romantic mythography, involved in the shaping of contemporary tourist experience, help the tourist agents realize as a deeper knowledge of these elements could lead to an enhancing source for their practices in present times.
\end{abstract}

Keywords: culture, heritage, nostalgia, romanticism, tourism.

\section{INTRODUCTION}

Tourism, as a spatial metaphor of modern reason, which within the silhouette of the aesthetic paradigm, reflects a tendency to a (re)enchantment of the world, of redemption, of pleasure, wellbeing and freedom 1 , tourism supports in a "world set up of social meanings": techniques, moral, artistic, mythological, etc.; this set of collective representations shapes the "cultural system" of a company or its "symbolic structure" around which a society organizes its production "of sense" (Beriain, 1990: 27).

In that world it is possible to extract elements of romantic mythography, involved in historical modeling of the tourist experience, whose analysis may maximize its source of enhancement.

Thereof our main analytical concern with some romantic topoi, though constructed in widespread discursive forms, whether they present themselves in literary, iconographic, or other rhetorical scenarios. This matter is all the more pertinent as some forms of rhetoric used by tourism agents as a predisposing strategy to the mobilization of travelling and may fall under Löwy's (1995: 250) allusion that:

"cultural industry often appropriates a few romantic clichés - the idyllic life of rural areas, love that reveals itself stronger than the barriers of money or social class, the incorruptible individual who does not allow himself to be bought - to integrate them in a superficial way in a fundamentally apologetic set and submitted to the dominant values. In this case, the romantic elements are neutralized or disfigured by the elimination of their critical behavior, diverted to the benefit of an essentially mercantilist culture."

\footnotetext{
${ }^{1}$ Concepts so peculiar to the romantic operating structure, with which it seems to have been shaped, suggesting that "since the first Romanticism one repeatedly calls for mystical and aesthetic experiences-limits to give the subject a means of overcoming exaltation." (Habermas, 1990: 287).
} 
To take forward the cognitive mapping of tourism implies, then, to deepen some of the logics that cover the romantic costumes of the tourist universe, bringing to the debate some more central elements of that movement, observing, with them, the submission of the imaginary of the individuals to programs responsible for tourist practices.

\section{The RoMANTIC SPIRIT OF THE JOURNEY}

In the nineteenth century, time that Schlegel (1980: 36) calls as "time of the knights, love and tales; thereof the [romantic] phenomenon and the word itself is derived", in Europe an elite of high society and liberal professionals emerges who, having the time and means to travel, is dedicated to the discovery of new territories, presenting different motivations of the underlying to travel in the Renaissance.

So, in the second half of the eighteenth century, with the vibrant intellectual travelling, philosophers such as Voltaire, Diderot, Rousseau express the diversity of customs that characterize the peoples of the world, along with the production of travel narratives by authors, such as Constantin François de Volney (1757-1820), who demystify the previous tales of fantasy voyages, establishing a positive language of cosmopolitanism ${ }^{2}$.

At the dawn of that century, journeys gain a logic of internal sense to itself. A sense that manifests itself with the celebration of nature as an opposition to the mercantilist and industrializing spirit of the time. Dissociated from the characteristics outlined by Bacon, it now focuses on the search for exotic landscapes and customs, as well as for milder climates as compared to the harsh Central European winters.

In the modern emergence of the tourist term ${ }^{3}$ a summary figure of this double traveler/philosopher seems to reside. "Is it reasonable to oppose philosophers to travelers, pragmatists to theorists; Rousseau and the Observers of Man?" (Kilani, 1994: 95). There would be a negative reply, since it is in this synthesis that rhetoric intersects over the real, and the journey would start to project itself as a modeling element of the social production of space ${ }^{4}$.

In an antinomian language to the absurd, from Chateaubriand to Baudelaire, the romantic narrative puts on stage the successful literary tourism. The romantics are animated by a new enchantment, requiring a prosaic world wrapped in a rewarding aesthetic cloak. That greatness of soul that sometimes becomes a simple exaltation of possessive individualism, flooded with violent passions and fantastic visions, evokes the authentic or imaginary heroes, refusing ostentation, career of honors and the boring daily life. A new geography of the soul that expresses itself, mainly, hostile to mechanical artificiality, as argued by Löwy: "nostalgic of the lost harmony between man and nature to which they devote a mystical cult, they observe with melancholy and desolation the progress of the machine, industrialization and the mechanized conquest of the environment"5.

In a failed escape from the contradictions of the prosaic modern world, those entertainments seek to mislead the chronometer of the Industrial Revolution and the cold calculation, which elements would enable the essential nexus between the corrupting spaces of the bourgeoisie associated with the Machiavellian conspiracy of technology.

A second manifestation of harmonious reunion with the world is its transformed permanence within bourgeois society. It can either take the form of dandyism or aesthetics, of a Saint-Simonian utopian

2 Europeans begin to see themselves as citizens of the world, and it is at this time that the cosmopolitan neologism is stated. Cf. Moravia, (1982).

3 The tourist term appears in London, precisely in the Romantic period, with a pejorative connotation on the part of the population, to designate those who made the Grand Tour through the European continent towards the south of France and Italy. Since 1811, it means, explicitly, the theory and practice of pleasure travel.

4 The relationship system organized from tourism has a visual change of the world (Gestalt). The tourist changes the world and the latter changes him, through the possibility of seeing and showing that world in a different way, seeing and showing himself with it. The way and the condition of being a tourist are already subject and product of perceptions of the world attached to the materiality and symbolism of daily life that grant him a perception of the world.

5 Op. cit., 63. 
experience, or simply embrace the passion of love. That is why muses sung in tears gain a momentum, countries visited in imagination, times evoked with enthusiasm and vivacity are constituted as refuges that trigger the evocation of a new annihilating aesthetic of the sovereignty of classicism.

Driven by the great travelers, curious about everything related to the life of people, expressed by a Biological and Cultural Anthropology, the romantic frame of the tourism is developed in a taste determined by nature resulting, to a large extent, in the dissociation of the feelings regarding theoretical reason and practical reason. From the travel narratives we can perceive experiences held in an outer space where unforeseen and adventures may occur with greater probability.

In an iconographic fascination, where travel still takes the center of the tourist experience, and destinies develop with the status of accident, individuals have a naturalistic and scientific view of the world. Such a view seems stimulated by Darwin's expeditions, by Vidal de La Blache's studies on the influence of the natural environment on man, as well as by the famous travel narratives of James Cook, Andersen, Stendhal, or Garrett, besides being considered as lovers of educated literature, art, and exoticism. Romanticism discloses tourism among the ascending bourgeoisie, mimicking the aristocratic habits. The actions of the travelers and explorers of the African and American continent who travel at the service of the royal courts and high finance, promoting the creation of Societies of Geography, with studies related to the knowledge of other cultures, are disseminated.

New peoples emerge in a logic of building borders between the corrupted «We» and the angelic «Other», prefiguring direct contact with nature and its exaltation. It is this Other, somewhere outside the city, between the sky, the sea and the undefined space that Rousseau had already recovered, which will provoke a symbolic change evidencing that the cultural space does not refer as much to geography as to history.

Time has arrived for the European to integrate the "good savage" into his genealogy as a living fossil species, a sign of a "deferred we". "«They» were not incorporated into universal history but projected into historical distance, and assimilated to our own past. In modern perspective, the other is thus a deferred «We»" (Kilani, 1994: 20).

The boundaries between «Them» and «Us» open up to the category of foreigners, who now turn to anthropological rhetoric, "an ideological problem before it is even a scientific problem. [...] In other words, the European, or more generally the observer of the dominant society, produces by distortion the idea of the savage, the uncivilized or the primitive" 6 . The representations of the Other resemble the hidden Us, who recognizes cultural difference as the foundation of different projects, integrated into the same universal project and the Other, who is inscribed "in the universalistic promise of a «unified and equal» humanity and the relativist Creed of «equality in the difference» appeared fallacious in their own principle"7. The principle of difference prevails over that of equality, in an asymmetry where the naturalistic philosophical universalism works the egalitarianism of identities, by a prism where it is "always our society that defines the general picture in relation to which the others are situated. Our conception of the universal is inherited from the philosophical thought of the eighteenth century which has always perceived equality "as the equalization of identities, which would be done, indeed, for the benefit of the [dominant] class» 8 .

In fact, since the Enlightenment, the good savage is an intellectual artifice: "the function of the savage is between the history and the utopia of populating the political space where the European man ventures, from the Renaissance to the Century of Enlightenment [...] we are not interested in the wild world except in that it offers Europe the image of its past, or a still darkened present" (Rolin, 1979: 75).

In this scenario, the elitist imaginary over which the myth of origins stands, is no longer dissociated from tourism, but instead becoming one of its fundamental pillars.

In a movement rich in correspondences and homologies among themselves, the romantic seal flows
6 Ibid.
${ }^{7}$ Ibid.
${ }^{8}$ Idem, 19. 
"either between lonely «travellers» from last century, not the professionals or scholars, but those who travel by temperament, pretext, or occasionally, that we will find a prophetic vocation of spaces where neither the identity, nor the relation or, evidently, as individuality, where only the movement of images makes possible, by a split of second, to the one who sees them escaping, the hypothesis of a past and the possibility of a future" (Augé, 1994: 93).

Time, space and the Other, from a new visual culture, invite to the foundation of tourism in a project suggestive of the idea that one of the tops of the romantic tourism culture is based on aesthetic individualism ${ }^{9}$.

\section{RADICAL SUBJECT AND ROMANTIC LIMINALITY}

Continuing this analysis will imply the confrontation with the emergence of new qualities and forms of expression operated in the conduct and sensitivity models 10 of the individuals, well captured by Simmel in The Metropolis and Mental Life.

Core value to romanticisms, radical subjectivism invests in the Self as permanence, but also as the liminality of individuals, as a rupture with everything that may be transformed in the non-Self, well expressed in the occasional disruptions of radicalization with society, with tradition, when it is established within the normative rules ${ }^{11}$. It is not surprising that, in romantic expressions, the challenge to rules, to rational, to obsession of the different, to desire for permanence in rupture, in transgression, prevail. Indeed, illusion persists as long as the fascination of consciousness lasts, trapped in the ambivalence between "the reified objectivity of social relations and rebellious subjectivity" (Marcuse 1977: 20).

The romantic feeling substantiates the outburst of feelings, the irrepressible flood of passion that remakes the universe, the incorporation of ludic as a ritual inscribed in a time strategy of apotheosis, conducive of "happy outbursts regarding the pleasure principle" (Lacan, 1979: 62 ).

A Dionysian time of entertainment, pleasure and oblivion emerges, in which the intimate is pressured as by an alien force to individuals, based on an antinomy natural man-social man, which sends back to nature the regenerative solution of social contradictions and generates fluctuation ${ }^{12}$.

The fluidity of modern man, his poetic nihilism ${ }^{13}$, the extravagaria of travel, whose enthusiasm is directed to an absence ${ }^{14}$, are symptoms of a denunciation of the irrational dimension of rationality.

\footnotetext{
${ }^{9}$ Going beyond good and evil, aesthetic individualism contains, according to Harvey, a new contradiction: "the search for the aesthetic experience as an end in itself has become, indeed, the milestone of the romantic movement [...]. It has generated the wave of «radical subjectivism», «unbridled individualism» and «quest of individual self-achievement» (Harvey, 1996: 29).

${ }^{10}$ Models that the Elisian theory discusses in the interdependence between subjects, life in society, routine and pleasure. See Norbert Elias and Eric Dunning, The quest for excitement and the work developed within the civilizational Process.

${ }^{11}$ Romanticism (just recall Rousseau) reveals a different way of conceiving consciousness. This capacity ceases to be the knowledge of relative differences to be intuition, absolute difference, intuition of the radical difference between the self and the world. Acts of conscience do not hold judgments related with reasoning (reason), but are a reasoning in the propositional form of emotions and feelings. Feelings is what challenges individuals, what governs the feeling - i.e., the feeling and not the sensation.

12 This notion is translated by a legacy of modernity, in which individuals become figures object of opposing forces, neither entirely natural, nor perfectly integrated in the civitas.

${ }^{13}$ According to Ferraz (sd: 136), the individual caught by poetic nihilism is invested "from arbitrariness without the laws of the spirit of time, which by negation of the world and things, has conquered a ludic space of freedom in nothingness, it was deduced that the imitation and the study of nature was despised. The ludic space of nothingness is that of discretion, which escapes from reality, takes refuge in the fantastic and is lost in the void without force or form [...] The individual experience of emptiness found full expression in the figure of the aesthetic egoist, without world, without society or community, locked in a solitude that fantasy would gild".

14 Absences full of ethnographic meaning, such as those of Forster, Blumenbach, or even Bougainvillle (1770), whose trip around the world sensitizes public opinion to the question of the "savages". According to Marquard (1989: 52), "part of escape for non-accusation lies in the enthusiasm for absence: people are not accused when
} 
Hence the journey constitutes a duality and rupture in the search for identity, in a fusion between personal experience and the one given by the narrator to the stories, recorded in a longer time period. A time that is oriented by the value of the enunciator and takes care of the destiny of its heroes, in a direct or veiled autobiography.

The consciousness of the subject presides over the intuition of the radical difference between the self and the world. Thereof, according to Marquard, a large part of the resistance to tribunalization of modern life (justified in the court of reason or of aesthetics) is confused with the overvaluation of an ineffable individuality 15 encouraged by anthropological philosophy which, at the end of the eighteenth century, is animated by the genesis of the meaning of history.

Therefore, the "Self" coagulates in the irrepressible extravasation of feelings, which has in the passion the re-creation of the universe, and the sense of the journey that emerges in the free individual, the frivolous ecstasy of the Self in the indomitable nature, where those who have no place in the world, can escape from it.

This is an escape "for a non-accusation" 16 where it echoes the Rousseauian myth of the "Noble Savage", inviting the idealization of simple life in nature, where the landscape acquires a poetic objectivity. Hence, the bourgeois taste chooses regenerative mythic spaces, substitutes for the state of grace inherent to a divine theodicy, irrevocably lost, elevating nature to the condition of a profane redemption.

Whether it is an individual or a collective journey, it represents a relation of absence in the space that is left, but also a relation of identifying incubation, of anonymity within the space the experience is taking place. Now, a journey is a leitmotiv to take advantage of the scenic relational virtualities with nature and becomes a cornerstone of a new logic of development of socializable cultural forms. With it, one can cherish the freeing of forms, lightness, picturesque, exotic, in a impressionistic way, within a context of literary productions that catapult novels into spaces of return to the roots, in the quest for lost identities.

Barthes's (1964: 114) reference is not accidental: "the Hispanic ethnicity is thus reduced to a great classical ballet, a kind of well-behaved commedia dell'arte, whose improbable typology serves to mask the real conditions stage show, of social classes and professions". In fact, the bourgeois gaze on men reduces them to mere social introductions of a graceful romanesque decoration. This is understandable in light of an experience that has been pierced by the aestheticization of art, by the fascination of monumentality, but also of the Other, who glides into the condition of decorative element of that aesthetic scene. Despite the inequality of life in the visited countries, the latter are, according to Barthes, spaces symbolizing the liberation of the taboos imposed on individuals in their countries of origin, and the Other now holds a status of scenic decoration 17.

Rousseau would name this state of affection as "le sentiment de l'existence", where a cultural pantheism takes shape, associated to a new subjectivity inscribed in the matrix of authenticity. "Le

they travel, and partly are when they are preparing for the trip or upon their return when dealing with the results of the trip. Hence the fascination with the anthropology and ethnography activities, from the Forsters, Bougainvilles and Blumenbachs".

15 As Marquard (51) points out, "from the second half of the seventeenth century, the rapid growth of the individual means the rapid growth of his ineffability, as a response to the hypertrophy of legitimation/compulsion: as an escape from non-accusation. "

16 "Part of the escape for non-accusation lies in the need for anonymity that is inevitably produced by the burden (by the burden of public exposure that happens to beings who compel themselves to totally justify to themselves.) This passion for situations in which someone Is impenetrable and unidentifiable and thus inaccessible to issues of legitimacy, is satisfied by the virgin nature, which offers a vacation of the guilty Ego [...]" Ibid., p. 50.

17 In the mentioned article on the Blue Guide, Barthes points out bourgeois mythology regarding the "horizon" of the tourist experience: "like the hilly is flattered to the point of annihilating the other kinds of horizon, the humanity of the region also disappears for the sole benefit of its monuments. For the Blue Guide, men only exist as types. In Spain, for example, Basques are adventure sailors, Levantines cheerful gardeners, Catalans skilled traders, Cantabrians sentimental mountain-dwellers. We are, once again, facing that essence virus that lies at the bottom of all the bourgeois mythology of man (and that is why we find it so often)". Ibid. 
sentiment de l'existence", which means listening to the voice of nature from within and following it, implies, according to Rousseau (1959), a state that "stripped of any other affection is in itself a precious feeling of contentment and of peace which alone is enough to make this existence dear and sweet to anyone who is able to separate himself from all sensual and hearthly impressions which come unceasingly to distract us from it and to upset our sweetness here on earth". The picturesque becomes the visible face of a new mythical space, facilitating the awakening of feelings and passions, an inviting place when walking in nature as a way for individuals to find themselves. Bucolic landscape works even as a symbol of subjective emotions and states of soul, well expressed in an extensive monograph.

Sensitive beings to the ignominy of the oppressive, sad and inhuman world ${ }^{18}$, choose the evasion, the escape, under cover of anonymity 19 , as a form of relief regarding the super-tribunalization 20 of life, to negativity 21 , to the return to a state of grace22. That escape from the experiences of the distressed daily routine, encouraged by the genesis of the meaning of history, contains, according to Marcuse, a potential danger of decentration of the subject23, which promotes "the evasion to a world of fiction where the existing conditions only change and supercede within the world of imagination" 24 .

In a culture that elevates the subject to its maximum power, the tourist "sightseeing" of the bourgeois romantic movement of the eighteenth and nineteenth centuries unveils the incorporation of the gaze into subjectivity, exploring new grounds for taste transformations. The imagination coagulates in such a way in the exaltation of the space, that the "objects" promoted to the esthetic existence influence the attitudes regarding the tourist trip. The "taste judgment", elevated to the sphere of aesthetic competence, is associated with contemplation, appreciation, perception, feeling and delight, sending reason to the place where affections converge giving expression to the subjective reality.

One fights the ambiguity of subjective affections, located in the "problematic of the indeterminate ("something that compelled us"), where the beautiful and taste are related, but also the graceful, the game, the fun pleasure" 25 , investing in its unveiling, through reason. As an intellectual faculty, taste judgment is a rational contemplation prerogative and nothing else than an ethical determination.

The expression of taste associated with a center of power come through transformations inherent to its social movement ${ }^{26}$. The taste, an eighteenth century concept developed in the topoi of the sensus communis of the humanistic formation tradition, is:

18 Absolutism, as the central figure of the accused man, takes the public space of the enlightened new man, marked by the filling of the post-theological void and the loss of self-justifying references, which hitherto swing between God's accusation taking into consideration a sinful conception of man and the relieving mediation of sin, a condition of his limited transgression capability, through absolutions generating intermittent states of grace, giving a break to total or absolute accusation status. (Marquard, op. Cit .: 48).

${ }^{19}$ Cf. Marquard, (op. cit., p. 51).

20 Idem, p. 50.

${ }^{21}$ Ferraz (op.cit. p.137) associates negativity "with the experiences [...] of the daily routine and its desperate and monotonous rhythm, once the mist of days and nights and games favouring death to life of man was distant. This affective mood, in which the emptyness was anxiously experienced, translated a subjectivity constantly threatened by the fugacity of the self aesthetic pleasure, by escaping the sense of existence after neglecting the complete metaphysical conception [...]. "The nihilism of this anxiety of time" is that subjectivity no longer owns time, instead it is owned by it. This romantic self is a victim of time and its temporality is simultaneously its annihilation".

22 Ibid., p. 49.

${ }^{23}$ To the extent that, "with an assertion of the interiority of subjectivity, the individual emerges from the entanglement of the exchange of relations and exchange of values, he withdraws from the reality of bourgeois society and enters into another dimension of existence. In truth, this evasion of reality led to an experience that could have (and could) become a powerful force in the invalidation of the main bourgeois values, namely, diverting the focus from individual achievement within the principle of achievement and from the profit motive for the intimate human resources: passion, imagination, consciousness "(Marcuse, 1977: 18).

24 Ibid., 15.

${ }^{25}$ Introduction to the work of Montesquieu (1995: 10) by António José Santana.

${ }^{26}$ On these transformations, Cf. Norbert Elias, (1992 a: 63). 
"A refuge of human freedom towards the justification needs, a resurrection of selfevidence (which has been lost somewhere)[...]. Like a court vacation, art becomes aesthetic; as art becomes autonomous and its inaccessibility becomes institutionalized, artistic work becomes, perhaps, more than anything else, the thing to which the [Leibnizian] question "By what right?" becomes silent" (Marquard, 1989: 53).

It is this distinctive taste that, for Gadamer (1960: 32):

"It is not only the ideal that gives rise to the new society, but for the first time it emerges under the sign of that «good taste» ideal, which since then has been called "good society". It does not identify or legitimize itself by birth and hierarchical level, but fundamentally (...) [by] its capacity of raising above the foolishness of personal interests and preferences, reaching the level of a true judgment [...]. Under the sign of good taste, one can reach a distance with oneself and with his personal preferences. Therefore, according to its own essence, taste is far from private, but a first class social phenomenon".

\section{ROMANTIC TIME AS REMINISCENT LEGACY}

Time reaches the romantic consciousness in the form of spaces projected as a reminiscent legacy, built up in the construction of narratives from the past. Glorified through travel, time evolves during the nineteenth century in the deepening of the historical roots and traces of national identities. For Turner and Ash (apud Aisner \& Plüss 1983: 34), "the rich and educated of the states where the position of domination is relatively new, visit the countries which grant them a sum of prestige and creativity, but which remains revered for cultural and historical reasons".

Travelling challenges writers, poets, and philosophers for the adventure of living their own history, as a personal experience and real-life scenarios. In an atypical time conjunction, abroad travelling is no longer imperative, as in the Renaissance, starting to incorporate the wonderful to the plan of each country, which is related to an aesthetically sustainable literature of nationality, associated "to the idea of the People, His Spirit or feeling" (Romano, 1981: 9). Now assuming more regionalizing characteristics, travel is not only an escape but also an intrusion. The visits also outline the meeting with a past preserved in the form of monuments, where the trip becomes the useful news place of the local actual world, widened by synecdoche to the most comprehensive realities.

In a mobility developed in macro-sequences there are always spaces corresponding to successful visits by tourist-archaeological wanderings in the visited cities, consuming little or badly delimited time between trips and stay. The story is more "true" when embedded with local colors and the character of the pawns placed in their own time and even more "authentic" when placed into the space of the occurrences. Extreme boundaries: on the one hand, erudition, moderating reason, the Greco Roman; on the other, the popular, the sensibility, the imagination, the genius, the countryside, the autochthonous Gothic. Aisthesis is emphasized in the sensitive relationship subject/object, not as a reference to the recent institutionalization of aesthetics, but in Baumgarten's sense of "emancipation of the senses" (Esperança, 1997).

Allusions to the sensory appropriation of the world flourish in this path. The "sensation" is restricted to the subject who experiences the pleasurable, in the most purist sense of his capacities, enclosing the aesthetic in the ethereal pleasure of subjective reflection, in the detachment of the suprasensitive and transcendental, as real life significance categories.

When images are the primordial operators of the condition of thinking the object (spaces, things, people and their works), they seem to be holders of objective reliability. And the major problem is that the imagery perception only reflects the appropriation of the object in the form of «partial and non-integrated images» (Miranda, 1979: 55), loaded with signs and symbols that make their perceptual appropriation "an active and creative process, which is the starting point of a cognitive synthesis" (Bailley apud de Miranda, 1979: 32-33). The symbolic selectivity of space is not natural but structured in significant landscapes.

\section{Romantic Fictionalization OF SPACE}

In the romantic soul there is an active sympathy for the world that promotes its openness to the infinite. Lefèbvre (1969: 369) would say that: 
"Imagination, for the romantic, is not only a function and a domain. It is a privileged experience, an activity, a productive investigation. Each stage involves the imagination that explores the present moment, the possible and the impossible. It plays a key role. The image, first externally, continues to deepen, on the one hand supported by symbolism, and on the other in the passionate movement it is invested".

Thus we return to a naturalistic pantheism which welcomes the solar metaphor, a new Aurora, which witnesses an attempt to jump beyond rationalism. Hence, in the nooks and crannies of the journey, spaces filled with a moral of effort and solitude similar to a bourgeois philosophy of desopression parade. They are evocative of "regeneration through the clean air, moral ideas in terms of heights, a rise as civilisation, etc." (Barthes, 1984: 113), through mountain peaks penetrated by the idyllic perception of the picturesque, bucolic exuberance of the countryside and the beach, as purifying spaces, where an authenticity is confused with the very act of living. It is understood that mountaineering becomes "the elementary, the virginity, the adventure" (Aisner \& Christine, 1983: 41), a lever for ascending to a state of unholy grace and that mountain resorts are devoted to health and to physical culture 27 . Everything converges into an active principle that assumes forms of restlessness, states of becoming, questions, struggles for aesthetic realizations, which the imaginary converts into regeneration "through spatial concepts that firstly emerge as canons of taste for the picturesque in the heart of the beginning of the Romantic movement of European art" (Soane, 1993: $30)$.

The ethnofictionist construction of virginity predisposes to the fascination of a prehuman world, projected in the "wilderness" compared to the "wild" nature - an idea that comprehends the mountain as a mythical boundary space. Therefore, travelling to the Alps, Pyrenees, eternal snow Himalayas, where tourists gravitate for religious, aesthetic or sporting reasons, is not accidental.

When museum archivism was enshrined to the invention of "parks and natural reserves" (Viard, 1984: 142), restitutionism flourishes in Europe, suggesting to Jeudy (1986: 7-9) that:

"beyond the obsessive pleasures of the objects' safeguard, a movement of consecration of all cultural signs emerges [...] Nothing seems to escape this archiving and classification [...] the words «patrimony», «collective memory», or «cultural identity» lose their conceptual power by becoming vague expressions that end up designating the exhaustion of their meanings".

This regenerating momentum is associated with the construction of landscaped palaces in rural areas and the European thermalism popularity among middle class, based on the therapeutic belief of mineral waters (Sharpley, 1994). When aesthetic-landscape naturalism is associated with the benefit of a healthy body, the perception of the place becomes galvanized.

Indeed, "there is no perception and physical space naturalism that would be later overwhelmed with social interests (where the «subjective» is added to the «objective»), since these are already symbolically marked by the experience" (Miranda , 1994: 55).

According to Barthes (op.cit. 113), the operators of the mystique of taste shall have as their standard reference:

"The Blue Guide [that] only knows the landscape under picturesque. It is picturesque everything that is rough land. Here we find again this bourgeois promotion of the mountain, that old alpine myth (dating back to the 19th century) that Gide precisely associated with the Helvetic-Protestant morality and which has always been a bastard myth of naturalism and puritanism".

Being this imaginary feeling overwhelmed by the erosion of its cosmogonic dimension, only a strong activation through the valuation of the altitude and the verticality, typical from the marvellous of a bright and vagary original nature, is left. For this purpose, an idyll rhetorical freedom is added to an appealing adjectivation of contemplative reverence and a call for panoramic views of heights, where centuries are admired, as well as monuments or historical events.

${ }^{27}$ See Turner Y Ash (1991: 290). 
Associated with the vulgarization of communications, European tourism flows denounce traces of an aesthetic naturalism, taken by the places that provide a more authentic and traditional view of the world, in a paradoxical process of detraditionalization of those spaces. In this regard, MacCannell (1976: 3) observes:

"For the modern, reality and authenticity are notions [...] that are found in other historical periods or in other cultures, as pure and simple lifestyles. In other words, what affects modern to «naturalism», their nostalgia and search for authenticity are not merely casual and somewhat decadent, notions of ties to memories of destroyed cultures and dead ages. They are also components of the modern conquering spirit the fields of their unifying consciousness."

In truth, they are diachronic perceptions of the "artificially preserved" cultural differences 28 , which are part of the romantic tourism motive.

\section{Preservation and InVEntion Of Tradition - Restitutionist Aporia}

The past, shrouded in melancholic nostalgia where "restitutionism occupies a privileged place" (Löwy, 1995: 93) in the constellation of the romantisms, can be mythological or legendary either as an imaginary reference of Atlantis or as consecration of a personal myth, such as is the case of the mysterious City, in Aurelia by Gérard de Nerval. In an idealized time, with a sense of loss and rejection of the social reality of his time, the journey is open to the preservation of tradition 29 .

Through the writing of the romantics, the places that populate the intimate geography of the individuals are detached from the spaces, emerging from that separation meta-narratives without territory, i.e., impressionistic descriptions of places. The imaginary references are manipulated by symbolic universes outside the places, holding codes that cut out the significant spaces from the places $^{30}$.

Their interpretations are a clamor of ethnocentrisms, kind of favorable outdoors to the gaze and imagination. Now, spaces are built tailored to the dreams of «Me», which integrate a divinization of mythical geniuses invented for the zones covered by classic artistic works. That classicism translates an identification with the past as

"one of the most popular route for evasion. The necessary evasion of everyday life has possibly its most conspicuous manifestation in evasion in time. In the same way that a weekend escape to a secondary residence by the sea or the mountain where the maternal nature is more closely felt, a projection to uterine regression, the journey to the past offers successive getaways that lead to longed-for refuges, which are believed to cope with the intemperance of everyday life" (Ballart 1977: 49-50)

The iconographic fascination for the countryside, from "modern" countries to the "exotic" ones, or for a space "elsewhere, which is preserving now a more primitive past, is contributing for the evasion. The attempt of exoticism is a search, by the simple displacement in space, of the past at the same moment it happens" (Löwy, 1995: 43). It is an evasion solified by a speculative and critical attitude towards the present 31 .

Strengthening a new social consensus alternative to the Old Regime, the subjectivist and anthropomorphic character of romanticism places the aesthetic expression of the world under its demystification, autonomizing it from tradition.

The romantic experience is related to a sequence of movements which establish a concentration at the same time subjective - the discovery of the self - and the sociability (the valorization of the

\footnotetext{
28 Ibid. p. 8.

29 See Campos (1999: 49).

30 This invention of tradition, as a cultural reality thoroughly produced by the state and not by local traditions, is designated by Bourdieu (1994: 106) as a "legitimate national culture" as a mythical attribution of status to places.

31 On the relationship between tradition/romanticism, cf. Arendt (1972: 38-39).
} 
Volksgeist), in a dichotomy that helps to recall its implication in the rootedness of the esthetic experience ${ }^{32}$.

The trip becomes social practice, recovering the cultural heritage, integrating it as a past in a present filled with the aesthetic-historical momentum of the origins. Thus we can understand the anathemas directed to noveau riche perspectives, blind to the relationship between tourism and heritage appreciation.

Travel suggests an option for rationally led progress and a present aiming to make a useful recovery of the past, guided by ideals prefigured by Don Quixote, plagued by the insoluble contradiction of the selfish individualism of Sancho Panza's barons 33 .

The romantic path sediments the historical imaginary status, dominating the time axis, which intersects with reports of sightseeing tours with abundant notes of places and landscapes. It is to this imagery that Bernard S. Cohn alludes, when analyzing the origin of the spirits of the places, animated by landscapes, myths and legends. The phenomenon gets a double aspect: the "internal", evident in the argument of "Pritchard [that], in fact is part of a broad movement that aimed to make the Welsh understand that they should treat their landscape with affection; to clearly show this, he gave a human and historical interest to each stick or stone" (Hobsbawm and Ranger 1984: 96); the external one, with the invention of references with instrumental objectives of tourist activity 34 .

That past is described by Ballart (1977: 50) as:

The ideal passport to get to lost paradises through a time tunnel that feeds our fantasy and helps us make up for lost time. What else but fantasy drives the enthusiasm of the devotees of epic movies or historical novels? And visitors of so many tourist attractions, including museums, that proliferate in old Europe or the new America, based on historical and archaeological heritage? Fantasy sets us free, while the time we grant to the past renews us as we regain the «lost time» we desire for ourselves, and not for the evil prizes of everyday's dull life.

The past is transmuted into the ideal bourgeois historical synthesis, taking shape in the monuments, in the folklore revaluation, as opposed to the culture without national roots. But he is also present in the scenic setting of the picturesque that becomes deeply dialectical in the "untouched" landscapes that describe the spaces as «magnificent, picturesque, or charming» (Boyer 1994: 10), which integrate a large part of the contemporary tourist imagination.

Spaces and memory converge in splendor, where crystallization in time takes care of preserving its face. As if the paradox of the invented authenticity, to enjoy the aura of the authentic, should be subtracted from new forms or from "technical reproducibility" 35 . In them lies the illusion that there is more past within it than in all civilization. There we can find the aesthetic genius, as if the oncebuilt world was doomed to become an ecstatic beauty.

\section{CONClusion}

Altogether, this text shows how it is possible for a certain narrative to act as a trigger for a strong aesthetic representation of culture, involved in strategies for mobilizing the geographical imagination.

If, in case, romanticism is not a season movement, but one of the timeless cornerstones of modernity, if the romantic metaphor shows evidence that it is not an intermediary of an aesthetic dispute that only acknowledges tourism as an instrumental guide to its practices, then it can be in-depth used as a successful guide for the tourist agents, as long as the different historical records are safeguarded.

\footnotetext{
32 According to Harvey(op. cit. 29), the aesthetic experience "has generated a wave of «radical subjectivism», of «unleashed individualism», and «the pursuit of individual self-realization»" which [...] had long established a fundamental conflict between cultural behavior and modernist artistic practices and the protestant ethic".

${ }^{33}$ In reference to Garrett (1994: 25).

${ }^{34}$ Ibid. p. 97.

${ }^{35}$ See Benjamin (1992: 77-78).
} 
In a conjunction where tourism is as magical as it is controversial, the necessary awareness of tourism agents and other actors in the "field" is presented with the decisive question of the understanding that, in the era of reinventing spaces, with the growth of Tourism demand, the restitution affirmation is an imperative, or rather if tourism needs ideo-cultures to survive, the dynamic preservation of the Other (identity) and cultural and natural assets may be an intrinsic requirement to the "field" itself ( patrimonial).

\section{BIBLIOGRAPHY}

Aisner, P. \& Plüss C. (1983). La Ruée Vers Le Soleil, Le Tourisme à Destination du Tiers Monde, Paris, L'Harmattan.

Arendt, H. (1972). La crise de la culture, France, éditions Gallimard.

Augé, M. (1997). L'Impossible Voyage, Le tourisme et ses images, Paris, Éditions Payot \& Rivages.

Augé, M. (1994). Não-Lugares, Introdução a uma Antropologia da Sobremodernidade, Lisboa, Bertrand.

Augé, M. (1998). A Guerra dos Sonhos, Exercícios de etnoficção (trad. de Miguel Serras Pereira), Oeiras, Celta Editora.

Ballart, J. (1977). El Patrimonio histórico y arqueológico: valor de uso, Barcelona, Editorial Ariel.

Barthes, R. (1964). Elementos de Semiologia, (trad. de Maria Margarida Barahona), Lisboa, Edições 70.

Barthes, R. (1984). Mitologias, (trad. José Augusto Seabra), Colecção Signos, Lisboa, Edições 70, $\mathrm{Ld}^{\mathrm{a}}$.

Benjamin, W. (1992). Sobre Arte, Técnica, Linguagem e Política, (trad. de Maria Luz Moita), Lisboa, Relógio d' Água Editores.

Beriain, J. (1990). Representaciones Colectivas y Proyecto de Modernidad, Barcelona, Editorial Anthropos.

Boyer, M. e Viallon, P. (1994). La communication touristique, Que sais-Je?, Paris, Presses Universitaires de France.

Bourdieu, P. (1994). Razões Práticas - sobre a teoria da acção, S. Paulo, Papirus Editora.

Campos, Joaquín Rodríguez, (1999). También se puede inventar la naturaleza? El poder del Lenguage de la cultura posmoderna. Etnográfica, Revista Semestral de Antropologia do Centro de Estudos de Antropologia Social (ISCTE), Lisboa, Edição Celta, Vol. III, n. ${ }^{\circ} 1$, May 1999.

Esperança, J. (1997). Património, comunicação, políticas e práticas culturais, Lisboa, Colecção Vega Universidade.

Ferraz, M A. (sd) A Ironia Romântica, Estudo de um processo comunicativo, Estudos Gerais, Série Universitária, Lisboa, Casa da Moeda

Garrett, A. (1994). Viagens na Minha Terra, Lisboa, Editores Reunidos, Ld. a e R.B.A. editores S.A.

Habermas, J. (1984). Mudança Estrutural da Esfera Pública, Rio de Janeiro, Tempo Brasileiro.

Habermas, J. (1990). O Discurso Filosófico da Modernidade, Lisboa, Publicações Dom Quixote.

Hans, A. (1971). Uma visita em Portugal em 1866, Lisboa.

Harvey, D. (1996). Condição Pós-moderna - Uma Pesquisa sobre as Origens da Mudança Cultural, $6^{a}$ edição, São Paulo, Edições Loyola.

Hobsbawm, E. e Ranger, T. (org.), (1984). A Invenção das Tradições, (tradução de Celina Cardim Cavalcante), Rio de Janeiro, Editora Paz e Terra.

Kilani M. (1994). L'invention de l'autre, Essais sur le discours anthropologique, Paris, Éditions Payot Lausanne.

Lacan, J. (1979). O Seminário, os quatro conceitos fundamentais da psicanálise, (versão brasileira de M. D. Magno), Rio de Janeiro, Zahar Editores.

Lefèbvre, H. (1969). Introdução à Modernidade (trad. Jehovanira Chysóstomo de Souza), Rio de Janeiro, Editora Paz e Terra S.A.

Löwy, M. Sayre R. (1995). Revolta E Melancolia, O romantismo na contramão da modernidade (trad. Guilherme João de Freitas Teixeira), Petrópolis, Vozes. 
MacCannell, D. (1976). The Tourist, A new theory of the leisure class, New York, Schocken Books. Marcuse H. (1977). A Dimensão Estética, (trad. de Maria Elisabete Costa), Lisboa, Edições 70.

Marquard Odo, (1989). Farewell to Matters of Principle, Ódeon, Oxford, Oxford University Press.

Miranda, J. (1994). Analítica da Actualidade, Lisboa, Veja.

Montesquieu (1995). Ensaio sobre o Gosto, Seguido de Elogio da Sinceridade, Lousã, Usus Editora.

Moravia, S. (1982). Filosofia e scienze umane nell' età dei lumi, Sansoni, Firenze.

Rolin, O. (1979). Bougainville et le mirage tahitien. L'Histoire, n. ${ }^{\circ}$ 8, janvier 1979.

Romano, Roberto, (1981). Conservadorismo Romântico, origem do totalitarismo, São Paulo, ed brasiliense S.A.

Rousseau, J. (1959). Les Rêveries du promeneur solitaire, «Cinquème Promenade». Oeuvres complètes, Paris, Gallimard, 1:1047.

Schlegel, F. (1980). European Romanticism: Self-Definition, ed L. Furst., London, Methuen.

Sharpley, R. (1994). Tourism, Tourists \& Society, Cambridgeshire, ELM Publications.

Soane, J. (1993). Fashionable Resort Regions: their evolution ans transformation, Cab International, Wallingford.

Stendhal, (1838). Memoires d'un touriste.

Turner L. Y Ash J. (1991). La Horda Dorada, Turismo Y Sociedad, Madrid, Ediciones Endymion.

Viard, J. (1984). Penser Les Vacances, ed. Actes Sud H., Paris, Nyssen. 